\title{
Angiotensin II regulates migration in mouse cultured mesangial cells: evidence for the presence of receptor subtype-specific regulation
}

\author{
Yuichiro Takeuchi, Keishi Yamauchi, Junko Nakamura, Satoshi Shigematsu and Kiyoshi Hashizume \\ Department of Aging Medicine and Geriatrics, Graduate School of Medicine, Shinshu University, 3-1-1, Asahi, Matsumoto-Shi, Nagano 390-8621, Japan \\ (Requests for offprints should be addressed to Y Takeuchi; Email: takeuti@hsp.md.shinshu-u.ac.jp)
}

\begin{abstract}
The biological effects of angiotensin II (AngII) are mediated by two major subtypes of AngII receptors, type 1 (AT1R) and type 2 (AT2R). In this study, we attempted to elucidate the role of AngII subtype receptor-specific regulation in migration and proliferation of mouse cultured mesangial (MSG) cells. We found that $100 \mathrm{nM}$ AngII stimulated weak migration of MSG cells. Cell motility increased more in the presence of AT2R than in the presence of AT1R, and it was suppressed by guanylate cyclase inhibitors. On the other hand, the activation of AT1R resulted in increased cell numbers, while AT2R activation inhibited cell proliferation. Moreover, high concentrations of glucose $(25 \mathrm{mM})$
\end{abstract}

stimulated the expression of AT2R but not AT1R. These results indicate that there are receptor subtype-specific roles in MSG cells, and it is therefore possible that the activation of AT2R stimulates repair of glomerular tissue defect, by regulation of migration and proliferation of MSG cells. Taken together, these results suggest that the relative concentrations of AT1R and AT2R are important factors in the regulation of AngII function in glomerular tissue, and alterations in the concentrations of these receptors may contribute to progression of or protection from diabetic nephropathy.

Journal of Endocrinology (2006) 191, 361-367

\section{Introduction}

Angiotensin II (AngII), a major component in the reninangiotensin system (RAS), plays a primary role as a vasoconstrictor in controlling cardiovascular function and renal homeostasis. Besides its action as a potent hypertensive hormone, AngII has various biological effects on cell proliferation, migration, and invasion. Locally or systematically generated AngII influences vascular function in both physiological and pathological states via several mechanisms, such as induction of migration of vascular smooth muscle cells (Kohno et al. 2000), retinal microvascular pericytes (Nadal et al. 2002), and glomerular mesangial cells (Kohno et al. 1999). Available results suggest that AngII serves as a vascular remodeling modulator and also stimulates migration and growth of cells.

Overactivity of the RAS induces cardiovascular dysfunction and renal sclerosis (Matsusaka et al. 1996, Shibasaki et al. 2005). It has been reported that angiotensin converting enzyme inhibitors (ACEIs) and AngII receptor blockers (ARBs) have not only hypotensive but also renoprotective effects on the progression of several renal diseases, including diabetic nephropathy (Brenner et al. 2001, Lewis \& Lewis 2003, Rossing et al. 2003, Izuhara et al. 2005, Burnier \& Zanchi 2006). Both ACEIs and ARBs are known to prevent the progression of renal damage by inhibiting AngII-induced glomerular capillary resistance and production of extracellular matrix (ECM).

Mesangial cells play important roles in the pathogenesis of glomerular diseases such as glomerular nephritis, glomerular sclerosis, and diabetic nephropathy. Previously, we confirmed that mouse cultured mesangial (MSG) cells express two subtypes of AngII receptors (ATRs), namely ATR type 1 (AT1R) and type 2 (AT2R) (Lorenzo et al. 2002). It has been revealed that the stimulation of AT1R increases proliferation of mesangial cells and production of ECM, but the functional roles of AT2R in mesangial cells remain unclear. In this study, we attempted to ascertain the difference in functional roles between AT1R and AT2R in MSG cells, especially regarding cell migration.

\section{Materials and Methods}

\section{Cell and chemicals}

Mouse mesangial (MSG) cells were obtained from American Type Culture Collection (Manassas, VA, USA) and cultured in Dulbecco's modified Eagle's medium (DMEM) with $5 \%$ fetal bovine serum (FBS) for $72 \mathrm{~h}$ before utilization. AngII, CGP-42112A (a potent AT2R agonist), PD123,319 (a potent and selective non-peptide AT2R antagonist), methylene blue (a guanylate cyclase inhibitor), and 6-anilino-5,8quinolinequinone (a competitive inhibitor of soluble 
guanylate cyclase inhibitor) were purchased from Sigma Chemical Co. RNH-6270 (olmesartan medoxamil, a highly selective AT1R antagonist) was kindly obtained from Sankyo Pharmaceutical Co. (Tokyo, Japan). Anti-AT1R rabbit polyclonal antibody (aAT1R) and anti-AT2R goat polyclonal antibody (aAT2R) were obtained from Santa Cruz (Santa Cruz, CA, USA) (Sahajpal \& Ashton 2005). Anti- $\beta$-tubulin mouse monoclonal antibody (aTub) was obtained from Chemicon (Temecula, CA, USA).

\section{Cell migration assay}

Cell migration analysis was performed using a modified Boyden chamber method as previously described (Ikeo et al. 2001). MSG cells were trypsinized prior to experimentation. Cells were harvested with Ham's F12 media (GIBCO) plus $1 \%$ FBS, and the cell number was adjusted to $1 \times 10^{6}$ cells $/ \mathrm{ml}$. Two hundred microliters $\left(2 \times 10^{5}\right)$ of cells were placed onto $8.0 \mu \mathrm{m}$ pore cell culture inserts and incubated with $0.7 \mathrm{ml}$ serum-free Ham's F12 with $3 \mu \mathrm{g} / \mathrm{ml}$ type I collagen (BectonDickinson Franklin Lakes, NJ, USA) for $5 \mathrm{~h}$ in the presence or absence of test reagents. Cell migration was quantified by counting the number of cells that migrated through the pores. All non-migrated cells were removed from the inner surface of the insert membrane with a scraper, and migrated cells attached to the outer surface were fixed by drying, and stained with MayGrunwald and Giemsa stain solutions. The number of stained cells was counted with a microscope at a magnification of $200 \times$.

\section{Cell count}

Cell count was performed for estimation of cell proliferation. Harvested MSG cells were suspended and placed into the wells containing DMEM plus 1\% FBS in the presence of AngII $(100 \mathrm{nM})$ with or without ATR antagonists. Media were changed every $12 \mathrm{~h}$. After $72 \mathrm{~h}$, the number of cells was counted with a microscope at a magnification of $200 \times$.

\section{$A T 1 R$ and $A T 2 R$ expression}

MSG cells were grown to confluence in 24-multiwell culture plates. After 2 days, cells were incubated with DMEM containing 1\% FBS and various concentrations of glucose. Media were changed every $3 \mathrm{~h}$. After $9 \mathrm{~h}$, the cells were lysed or used in the ${ }^{125} \mathrm{I}$-AngII binding assay (as follows).

\section{Immunoblotting}

Immunoblotting was performed as previously described (Yamauchi et al. 2004). Whole-cell extracts were prepared by detergent solubilization of the cells in lysis buffer $(20 \mathrm{mM}$ Hepes (pH 7•4), 1\% Triton X-100, 2 mM EDTA, 100 mM sodium fluoride, $10 \mathrm{mM}$ sodium pyrophosphate, $2 \mathrm{mM}$ sodium orthovanadate, $1 \mathrm{mM}$ phenylmethylsulfonyl fluoride, $10 \mu \mathrm{M}$ leupeptin, $10 \mu \mathrm{g} / \mathrm{ml}$ aprotinin, and $1.5 \mu \mathrm{M}$ pepstatin) for $1 \mathrm{~h}$ at $4{ }^{\circ} \mathrm{C}$. For western blotting, $200 \mu \mathrm{g}$ protein of lysate was applied to each lane. Cell extracts were subjected to SDS-PAGE and western blotting using 1:1000 diluted aAT1R, aAT2R, or aTub primary antibodies and 1:20000 diluted horseradish peroxidase-conjugated goat anti-rabbit IgG, rabbit anti-goat IgG, or goat anti-mouse IgG secondary antibody respectively and visualized with the Enhanced Chemical Luminescence detection system (Amersham Pharmacia Biotech).

\section{AngII binding assay}

Cells were incubated for $1 \mathrm{~h}$ at $22{ }^{\circ} \mathrm{C}$ in $500 \mu \mathrm{l}$ of a medium containing $50 \mathrm{mM}$ Tris- $\mathrm{HCl}$ (pH 7.2), $150 \mathrm{mM} \mathrm{NaCl}$, $0.5 \mathrm{mM}$ EDTA, $1 \mathrm{mM} \mathrm{CaCl}, 0 \cdot 1 \% \mathrm{BSA}$, and $0.6 \mathrm{nM}{ }^{125} \mathrm{I}-$ Ang II (Amersham Pharmacia Biotech) with or without AT1R selective antagonist, RNH-6270, and/or AT2R selective antagonist, PD123,319. Incubations were terminated by immersion of the whole-culture plates into three successive baths containing ice-cold PBS. Cells were then solubilized in $500 \mu \mathrm{l} \mathrm{NaOH}(0 \cdot 1 \mathrm{M})$ and the associated radioactivity was determined by spectrometry. Nonspecific binding was determined by the amount of ${ }^{125}$ I-Ang II bound in the presence of unlabeled 50 nM AngII (Sahajpal \& Ashton 2005).

\section{Statistical analysis}

Statistical analysis was carried out using ANOVA with Fisher's protected least-significant difference (StatView, SAS Institute Inc., Cary, NC, USA). A $P<0.05$ value was considered statistically significant.

\section{Results}

Effect of AngII on migration of mesangial cells

AngII-dependent migration was observed in mesangial cells during cell culture. Levels of cell migration were low in the presence of $100 \mathrm{nM}$ AngII (Fig. 1). As both AT1R and AT2R are known to deliver counteracting signals for each other (Dinh et al. 2001), we examined the effect of ATR subtypespecific modification. In the presence of a selective AT1R antagonist, RNH-6270 AngII markedly increased migration of MSG cells (Fig. 2). Additionally, CGP-42112A, a selective AT2R agonist, promoted cell migration more strongly than AngII alone in a dose-dependent manner (Fig. 3). On the other hand, AngII in the presence of PD123,319, a selective AT2R antagonist, did not cause cell migration (Fig. 4). These results suggest that AngII induces cell migration via AT2R but not via AT1R in MSG cells. 


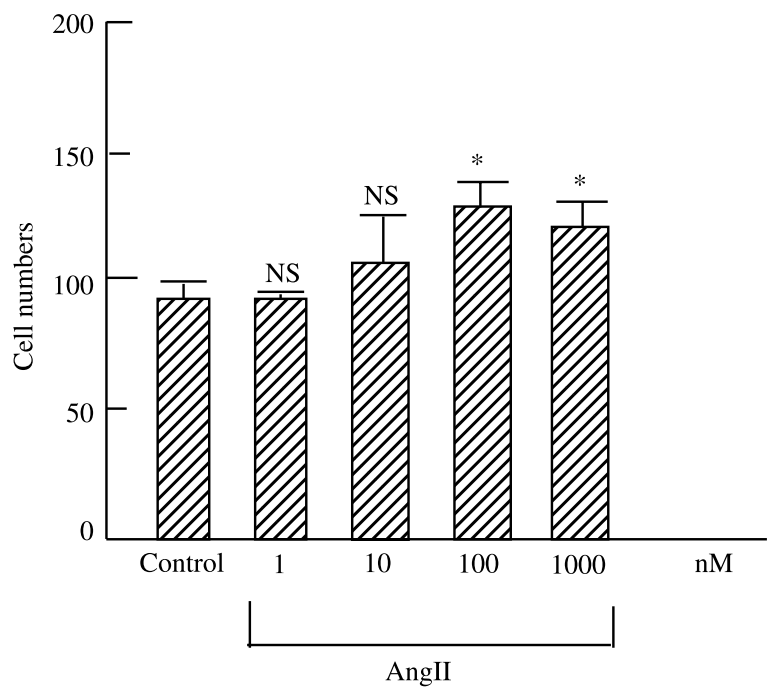

Figure 1 Dose-dependent effects of Angll on MSG cell migration. MSG cells were incubated with various concentrations of Angll for $5 \mathrm{~h}$ in a two-chamber system. Cells migrated slightly but significantly in a dose-dependent manner. Values are means \pm s.E.M. from three independent experiments. Each experiment was performed in duplicate. NS, not significant; $* P<0 \cdot 05$ versus basal migration.

Control

RNH-6270 $(10 \mu \mathrm{M})$

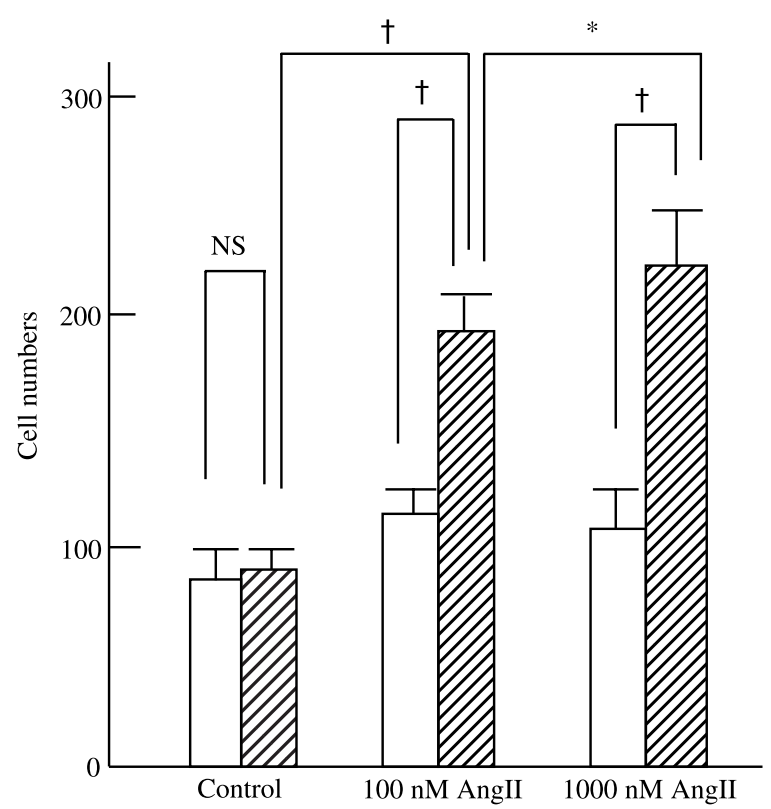

Figure 2 Effect of a selective AT1R antagonist (RNH-6270) on Angll-induced cell migration. Cells were incubated with or without $100 \mathrm{nM}$ Angll for $5 \mathrm{~h}$, in the presence or absence of RNH-6270. Presence of both the Angll and the A1TR agonist strongly stimulated cell migration. Values are means \pm S.E.M. from three independent experiments. Each experiment was performed in triplicate. NS, not significant; ${ }^{*} P<0 \cdot 05 ;{ }^{\dagger} P<0 \cdot 01$.

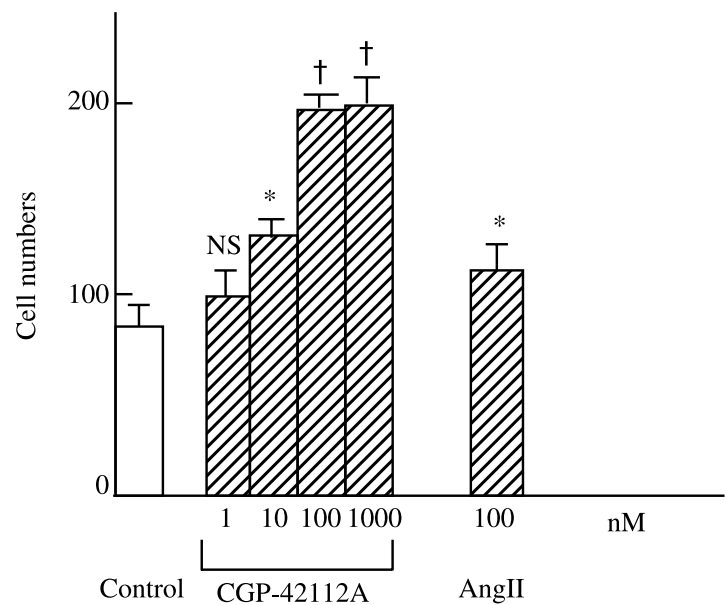

Figure 3 Dose-dependent effects of Angll and a selective AT2R agonist (CGP-42112A) on cell migration. MSG cells were incubated with various concentrations of CGP-42112A for $5 \mathrm{~h}$. Cells significantly migrated in a dose-dependent manner. Values are means \pm S.E.M. from three independent experiments. Each experiment was performed in duplicate. NS, not significant versus basal migration; $* P<0.05$ versus basal migration; ${ }^{+} P<0 \cdot 01$ versus basal migration.

Effect of guanylate cyclase inhibitors on AT2R-mediated cell migration

Signal transduction of AT2R is at least partly dependent on cyclic guanine monophosphate (cGMP; Horiuchi 1996). We therefore tried to clarify the efficacy of methylene blue and 6-anilino-5,8-quinolinequinone, two potent inhibitors of

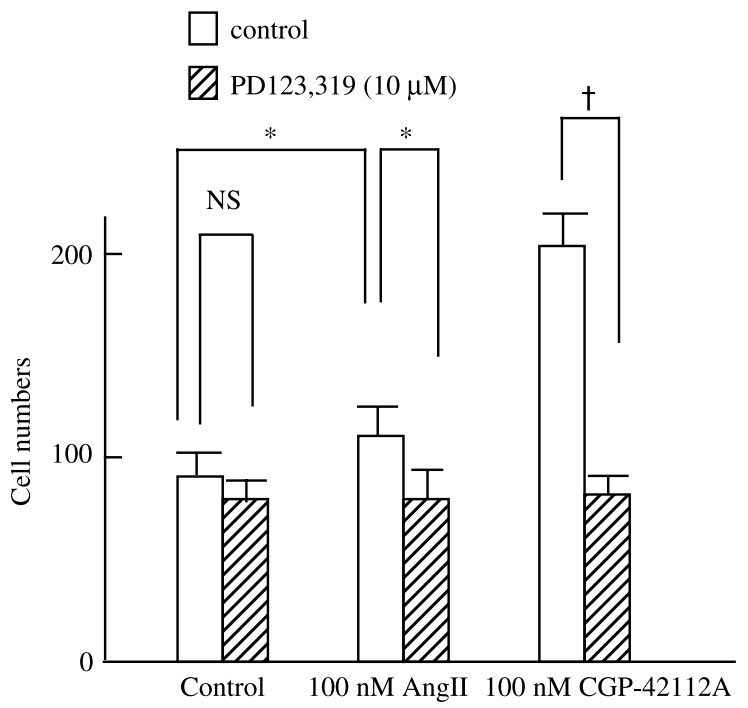

Figure 4 Effect of a selective AT2R antagonist (PD123,319) on Angll-induced cell migration. Cells were incubated with Angll or CGP-42112A in the presence or absence of PD123,319 for $5 \mathrm{~h}$. The presence of an A2TR antagonist suppressed both Angll- and CGP42112A-induced MSG cell migration. Values are means \pm s.E.M. from three independent experiments. Each experiment was performed in triplicate. NS, not significant; ${ }^{*} P<0 \cdot 05 ;{ }^{+} P<0 \cdot 01$. 
guanylate cyclase, on the migration via AT2R in mesangial cells. These reagents inhibited cell migration (Fig. 5), thereby indicating that mesangial cell migration is mediated by AT2R and is dependent on cyclic GMP production.

\section{Effect of ATRs' activation on cell proliferation}

AngII promotes not only cell migration but also cellular proliferation. We evaluated MSG cell proliferation by counting the number of cells. In the presence of $100 \mathrm{nM}$ AngII, treatment of PD123,319 but not RNH-6270 increased cell number (Fig. 6). These data suggest that AngII induces cellular proliferation through AT1R.

\section{Effect of glucose concentration on ATR expression}

We observed the effect of glucose concentration on expression of ATRs in MSG cells. It was found that high concentrations of glucose stimulated the expression of AT2R. On the other hand, expression of AT1R was not influenced by glucose. As a repetitive glucose spike is considered to be an important factor in endothelial cell dysfunction (Ceriello 2004, Azuma et al. 2006), we explored the effect of glucose fluctuation on ATR expression in MSG cells, and found that continuous exposure to high glucose more effectively induced AT2R than glucose fluctuation (Fig. 7A).

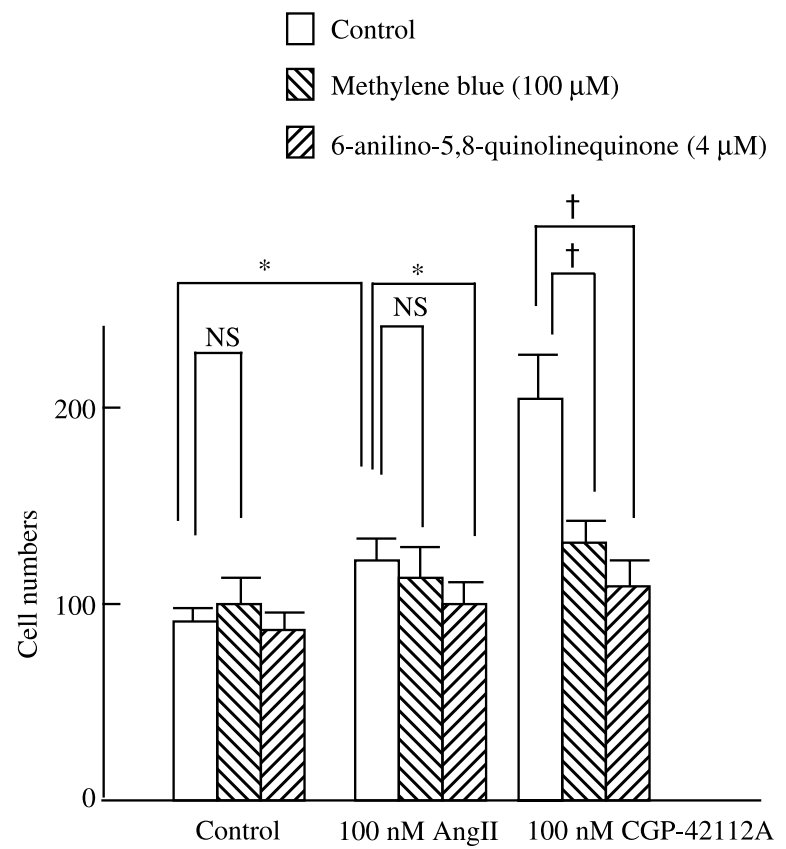

Figure 5 Effect of guanylate cyclase inhibitors on AT2R-mediated cell migration. Cells were incubated with or without $100 \mathrm{nM} \mathrm{CGP-}$ $42112 \mathrm{~A}$ for $5 \mathrm{~h}$, in the presence or absence of $100 \mu \mathrm{M}$ methylene blue or 6-anilino-5,8-quinolinequinone. Both guanylate cyclase inhibitors suppressed AT2R agonist-induced cell migration. Values are means \pm S.E.M. from three independent experiments. Each experiment was performed in triplicate. NS, not significant; ${ }^{*} P<0 \cdot 05 ;{ }^{\dagger} P<0 \cdot 01$.

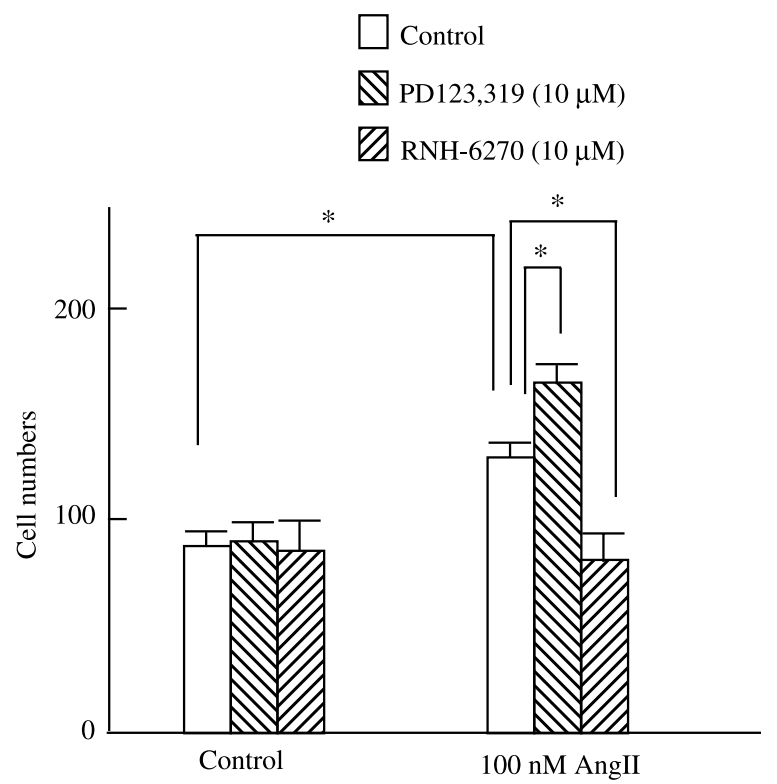

Figure 6 Effect of ATR subtype-specific stimulation on proliferation of MSG cells. Cells were incubated with $100 \mathrm{nM}$ Angll in the presence or absence of ATR subtype-specific antagonists (RNH6270 or CGP-42112A) for 5 h. Values are means \pm S.E.M. from three independent experiments. Each experiment was performed in triplicate. ${ }^{*} P<0 \cdot 01$.

In order to confirm glucose-induced ATR expression, we observed the effect of glucose concentration on displacement of ${ }^{125}$ I-AngII binding by ATR subtype-specific antagonists in MSG cells (Fig. 7B) and found that the binding assay demonstrated glucose-dependent alteration of binding capacities of ATRs. ${ }^{125}$ I-AngII displacement by an AT2R antagonist in $25 \mathrm{mM}$ glucose medium was significantly increased as compared with that in $5 \mathrm{mM}$ glucose medium. Displacement by AT1R was about fourfold larger than that of AT2R, but displacement levels by AT1R did not change in different glucose concentrations. These data suggested that $25 \mathrm{mM}$ glucose increased AT2R binding capacity of MSG cells but not AT1R. As binding capacity of ATR reflected ATR number (Sahajpal \& Ashton 2005), these data are compatible with the immunoblotting data.

\section{Discussion}

The RAS is a humoral cascade that plays an integral role in cardiovascular homeostasis by influencing vascular tone, fluid and electrolyte balance, and the sympathetic nervous system. Additionally, the RAS has been implicated in the development of various cardiovascular diseases, such as hypertension, congestive heart failure, coronary ischemia, and renal insufficiency (Dzau 1994). Renal AngII is involved in regulating sodium and water reabsorption from the proximal tubules and inhibition of renin secretion from the macula 


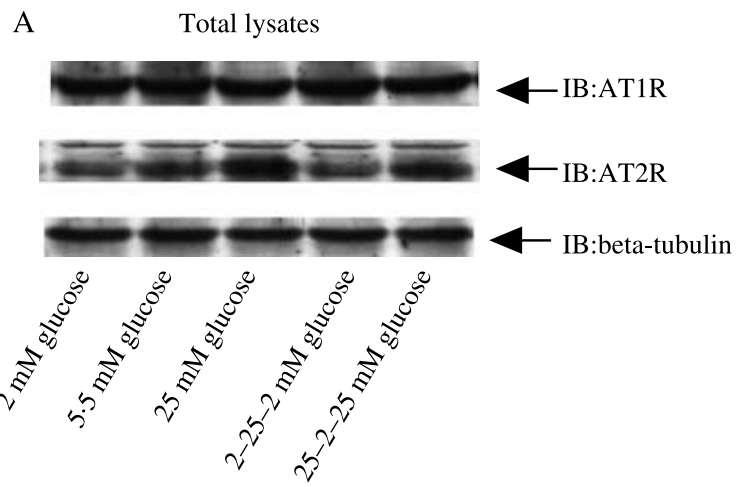

B

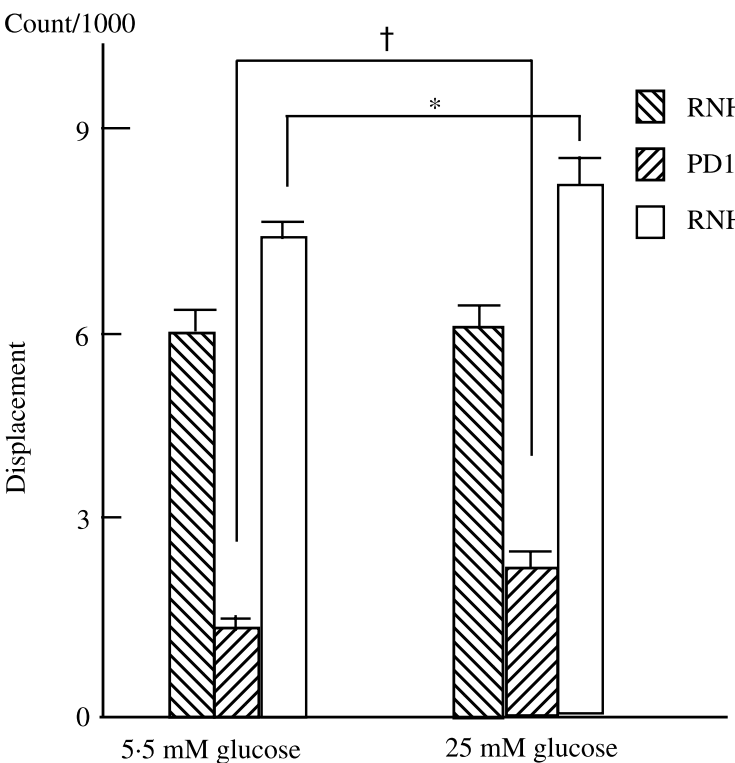

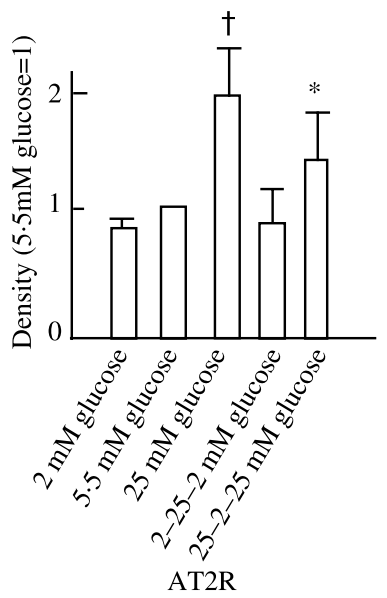

AT2R

Figure 7 Effect of glucose on ATR subtype-specific expression in MSG cells. (A) Cells were incubated with indicated concentrations of glucose for 9 h. 25-2-25 mM glucose indicates that cells were initially incubated in medium with high glucose $(25 \mathrm{mM})$ for $3 \mathrm{~h}$, followed by a rapid reduction of glucose to $2 \mathrm{mM}$ for the next $3 \mathrm{~h}$; media was then changed to a concentration of $25 \mathrm{mM}$ of glucose. $2-25-2 \mathrm{mM}$ glucose indicates that concentrations were changed at $3 \mathrm{~h}$ intervals, but concentrations were initially 2 , 25 , and then $2 \mathrm{mM}$ glucose medium. Whole-cell lysates were prepared as described in text and immunoblotted with an antibody directed against AT1R or AT2R. A typical immunoblot for the AT1R and AT2R in MSG cells is shown. The densitometry data are presented as relative density compared with density at $5.5 \mathrm{mM}$ glucose concentration. Values are means \pm S.E.M. from three independent experiments. ${ }^{*} P<0 \cdot 05$ versus $5.5 \mathrm{mM}$ glucose condition; ${ }^{\dagger} P<0 \cdot 01$ versus $5.5 \mathrm{mM}$ glucose condition. (B) Cells were incubated in medium with normal concentration of glucose $(5.5 \mathrm{mM})$ or high glucose $(25 \mathrm{mM})$ for $9 \mathrm{~h}$. Cells were then washed thrice with PBS. ${ }^{125}$ I-Angll binding assay was performed as described in text. Each bar indicates count of ${ }^{125}$ I-Angll displacement by co-incubation with RNH-6270 and/or PD123,319. Values are means \pm S.E.M. from three independent experiments. Each experiment was performed in triplicate. ${ }^{*} P<0 \cdot 05 ;{ }^{\dagger} P<0 \cdot 01$.

densa cells (Bell \& Peti-Peterdi 1999). Virtually all of the known biological actions of AngII, including vasoconstriction, release of aldosterone, stimulation of sympathetic transmission, and cellular growth, are exclusively mediated by the AT1R (Timmermans et al. 1992, 1993). In contrast, the functional role of AT2R is not fully understood. However, recent studies have ascribed a possible role for AT2R in the mediation of anti-proliferation, apoptosis, differentiation, and possibly vasodilatation (Horiuchi 1996, Csikos et al. 1998). 
It has previously been reported that both AT1R and AT2R are expressed in mouse cultured mesangial cells (Lorenzo et al. 2002). We observed that MSG cells weakly migrated in the presence of AngII $(100 \mathrm{nM})$. Considering this result, we anticipated that AngII might regulate migration of mesangial cells by receptor subtype-specific effects. AngII markedly increased migration of MSG cells in the presence of a selective AT1R antagonist (RNH-6270) in a concentration-dependent manner. Additionally, we demonstrated that a selective AT2R agonist also strongly induced migration of MSG cells. In contrast, AT2R antagonist, PD123,319, suppressed AngIIinduced cell migration. These results suggest that AngII induces migration of MSG cells via AT2R but not via AT1R. Recently, various second messengers coupled to the AT2R have been described, including indirect negative coupling to guanylate cyclase (Bottari et al. 1992) and activation of potassium channels (Kang et al. 1993, 1994).

We then analyzed the signal transduction of AngII through AT2R by observation of the effect of methylene blue and 6-anilino-5,8-quinolinequinone, and the other guanylate cyclase inhibitors on mesangial cell migration. Both methylene blue and 6-anilino-5,8-quinolinequinone inhibited AngII-induced migration of MSG cells via AT2R, suggesting that guanylate cyclase participates in signal transduction of AngII through AT2R, thus promoting cell migration.

In the kidney, it has been reported that an excess of AngII induces proliferation of mesangial cells and ECM, both of which are important factors in the induction and progression of renal injury (Wolf \& Neilson 1993). In fact, we confirmed that AngII causes cellular proliferation via AT1R. Recently, it has been reported that angiotensin converting enzyme inhibitors (ACEIs) and angiotensin II receptor blockers have renoprotective effects on the progression of several renal diseases, including diabetic nephropathy (Brenner et al. 2001, Lewis \& Lewis 2003, Rossing et al. 2003, Izuhara et al. 2005, Burnier \& Zanchi 2006). One possible explanation of these renoprotective effects is that these agents suppress proliferation of mesangial cells and inhibit production of mesangial matrix by blocking the effect of AngII through AT1R.

Importantly, the expression of AT2R is upregulated in pathological conditions, such as heart failure, renal failure, myocardial infarction, brain lesions, vascular injury, and wound healing (Kimura et al. 1992, Viswanathan et al. 1994, Nakajima et al. 1995, Nio et al. 1995, Ohkubo et al. 1997, Chung \& Unger 1998). We examined the effect of high glucose concentration on the expression of ATRs in MSG cells, because it is well known that a continuous hyperglycemic state contributes to the development of glomerular injury that is prevalent in diabetic nephropathy. Our results demonstrate that continuous high glucose concentration induces the expression of AT2R but not AT1R.

Cell migration and cell proliferation are fundamental responses of mesangial cells to glomerular injury and contribute to the hypercellularity observed in a number of glomerular diseases. On the other hand, cell migration plays an important role in repairing or remodeling damaged tissues. These findings suggest that the activation of AT2R contributes to repair or remodeling of injured kidney by induction of mesangial cell migration and suppression of MSG proliferation. Our data also suggest that expression of AT2R, induced by high glucose concentration, is a type of biological adaptation that promotes repair of injured glomerular tissue by enhancement of MSG cell migration.

In conclusion, we demonstrated that AngII induces mesangial cell migration through AT2R activation, and also that the nitric oxide (NO)-cGMP pathway might be involved in AT2R-mediated cell migration. Our data also showed that hyperglycemia induces AT2R expression in MSG cells. In injured glomerular tissue, the activation of AT2R in MSG cells may contribute to tissue repair by induction of migration and suppression of proliferation.

\section{Acknowledgements}

The authors declare that there is no conflict of interest that would prejudice the impartiality of this scientific work.

\section{References}

Azuma K, Toyofuku Y, Iesaki T, Otsuka A, Tanaka A, Mita T, Hirose T, Tanaka Y, Daida H, Kawamori R et al. 2006 Acarbose, an alfa-glucosidase inhibitor, improves endothelial dysfunction in Goto-Kakizaki rats exhibiting repetitive blood glucose fluctuation. Biochemical and Biophysical Research Communications 345 688-693.

Bell PD \& Peti-Peterdi J 1999 Angiotensin II stimulates macula densa basolateral sodium/hydrogen exchange via type 1 angiotensin II receptors. Journal of the American Society of Nephrology 10 S225-S229.

Bottari SP, King IN, Reichlin S, Dahlstroem I, Lydon N \& de Gasparo M 1992 The angiotensin AT2 receptor stimulates protein tyrosine phosphatase activity and mediates inhibition of particulate guanylate cyclase. Biochemical and Biophysical Research Communications 183 206-211.

Brenner BM, Cooper ME, de Zeeuw D, Keane WF, Mitch WE, Parving HH, Remuzzi G, Snapinn SM, Zhang Z \& Shahinfar S 2001 Effects of losartan on renal and cardiovascular outcomes in patients with type 2 diabetes and nephropathy. New England Journal of Medicine 345 861-869.

Burnier M \& Zanchi A 2006 Blockade of the renin-angiotensin-aldosterone system: a key therapeutic strategy to reduce renal and cardiovascular events in patients with diabetes. Journal of Hypertension 24 11-25.

Ceriello A 2004 Impaired glucose tolerance and cardiovascular disease: the possible role of post-prandial hyperglycemia. American Heart Journal 147 803-807.

Chung O \& Unger T 1998 Unopposed stimulation of the angiotensin AT2 receptor in the kidney. Nephrology, Dialysis, Transplantation 13 537-540.

Csikos T, Chung O \& Unger T 1998 Receptors and their classification: focus on angiotensin II and the AT2 receptor. Journal of Human Hypertension 12 311-318.

Dinh DT, Frauman AG, Johnston CI \& Fabiani ME 2001 Angiotensin receptors: distribution, signalling and function. Clinical Science $\mathbf{1 0 0}$ 481-492.

Dzau VJ 1994 Cell biology and genetics of angiotensin in cardiovascular disease. Journal of Hypertension 12 S3-S10.

Horiuchi M 1996 Functional aspects of angiotensin type 2 receptor. Advances in Experimental Medicine and Biology 396 217-224. 
Ikeo S, Yamauchi K, Shigematsu S, Nakajima K, Aizawa T \& Hashizume K 2001 Differential effects of growth hormone and insulin-like growth factor I on human endothelial cell migration. American Journal of Physiology $\mathbf{2 8 0}$ C1255-C1261.

Izuhara Y, Nangaku M, Inagi R, Tominaga N, Aizawa T, Kurokawa K, van Ypersele de Strihou C \& Miyata T 2005 Renoprotective properties of angiotensin receptor blockers beyond blood pressure lowering. Journal of the American Society of Nephrology 16 3631-3641.

Kang J, Sumners C \& Posner P 1993 Angiotensin II type 2 receptormodulated changes in potassium currents in cultured neurons. American Journal of Physiology 265 C607-C616.

Kang J, Posner P \& Sumners C 1994 Angiotensin II type 2 receptor stimulation of neuronal $\mathrm{K}$ currents involves an inhibitory GTP binding protein. American Journal of Physiology 267 C1389-C1397.

Kimura B, Sumners C \& Phillips MI 1992 Changes in skin angiotensin II receptors in rats during wound healing. Biochemical and Biophysical Research Communications 187 1083-1090.

Kohno M, Yasunari K, Minami M, Kano H, Maeda K, Mandal AK, Inoki K, Haneda M \& Yoshikawa J 1999 Regulation of rat mesangial cell migration by platelet-derived growth factor, angiotensin II, and adrenomedullin. Journal of the American Society of Nephrology 10 2495-2502.

Kohno M, Ohmori K, Nozaki S, Mizushige K, Yasunari K, Kano H, Minami M \& YoshikawaJ 2000 Effects of valsartan on angiotensin II-induced migration of human coronary artery smooth muscle cells. Hypertension Research 23 677-681.

Lewis EJ \& Lewis JB 2003 Treatment of diabetic nephropathy with angiotensin II receptor antagonist. Clinical and Experimental Nephrology $71-8$.

Lorenzo O, Ruiz-Ortega M, Suzuki Y, Rupérez M, Esteban V, Sugaya T \& Egido J 2002 Angiotensin III activates nuclear transcription factor- $\kappa \mathrm{B}$ in cultured mesangial cells mainly via AT2 receptors: studies with AT1 receptor-knockout mice. Journal of American Society Nephrology 13 1162-1171.

Matsusaka T, Hymes J \& Ichikawa I 1996 Angiotensin in progressive renal diseases: theory and practice. Journal of the American Society of Nephrology 7 2025-2043.

Nadal JA, Scicli GM, Carbini LA \& Scicli AG 2002 Angiotensin II stimulates migration of retinal microvascular pericytes: involvement of TGF- $\beta$ and PDGF-BB. American Journal of Physiology. Heart and Circulatory Physiology 282 H739-H748.

Nakajima M, Hutchinson HG, Fujinaga M, Hayashida W, Morishita R, Zhang L, Horiuchi M, Pratt RE \& Dzau VJ 1995 The angiotensin II type 2 (AT2) receptor antagonizes the growth effects of the AT1 receptor: gainof-function study using gene transfer. PNAS 92 10663-10667.
Nio Y, Matsubara H, Murasawa S, Kanasaki M \& Inada M 1995 Regulation of gene transcription of angiotensin II receptor subtypes in myocardial infarction. Journal of Clinical Investigation 95 46-54.

Ohkubo N, Matsubara H, Nozawa Y, Mori Y, Murasawa S, Kijima K, Maruyama K, Masaki H, Tsutumi Y, Shibazaki Y et al. 1997 Angiotensin type 2 receptors are reexpressed by cardiac fibroblasts from failing myopathic hamster hearts and inhibit cell growth and fibrillar collagen metabolism. Circulation 96 3954-3962.

Rossing K, Jacobsen P, Pietraszek L \& Parving HH 2003 Renoprotective effects of adding angiotensin II receptor blocker to maximal recommended doses of ACE inhibitor in diabetic nephropathy: a randomized doubleblind crossover trial. Diabetes Care 26 2268-2274.

Sahajpal V \& Ashton N 2005 Increased glomerular angiotensin II binding in rats exposed to a maternal low protein diet in utero. Journal of Physiology $\mathbf{5 6 3}$ 193-201.

Shibasaki Y, Nishiue T, Masaki H, Tamura K, Matsumoto N, Mori Y, Nishikawa M, Matsubara H \& Iwasaka T 2005 Impact of the angiotensin II receptor antagonist, losartan, on myocardial fibrosis in patients with endstage renal disease: assessment by ultrasonic integrated backscatter and biochemical markers. Hypertension Research 28 787-795.

Timmermans PB, Benfield P, Chiu AT, Herblin WF, Wong PC \& Smith RD 1992 Angiotensin II receptors and functional correlates. American Journal of Hypertension 5 221S-235S.

Timmermans PB, Wong PC, Chiu AT, Herblin WF, Benfield P, Carini DJ, Lee RJ, Wexler RR, Saye JA \& Smith RD 1993 Angiotensin II receptors and angiotensin II receptor antagonists. Pharmacological Reviews 45 205-251.

Viswanathan M, de Oliveira AM, Correa FM \& Saavedra JM 1994 Expression of a novel non-angiotensin II [ ${ }^{125}$ I] CGP 42112 binding site in healing wounds of the rat brain. Brain Research 658 265-270.

Wolf G \& Neilson EG 1993 Angiotensin II as a renal growth factor. Journal of the American Society of Nephrology 3 1531-1540.

Yamauchi K, Nishimura Y, Shigematsu S, Takeuchi Y, Nakamura J, Aizawa T \& Hashizume K 2004 Vascular endothelial cell growth factor attenuates actions of transforming growth factor-beta in human endothelial cells. Journal of Biological Chemistry 279 55104-55108.

Received in final form 11 July 2006

Accepted 26 July 2006

Made available online as an Accepted Preprint 22 August 2006 